\title{
"Nothing will satisfy you but money" \\ Debt, Freedom, and the Mid-Atlantic Culture of Money, 1670-1764
}

\author{
DANIEL JOHNSON \\ Bilkent University
}

\begin{abstract}
Politics in British America often centered on the issue of currency. Competing ideas about the nature of money and what constituted just relations of credit and debt also pervaded everyday colonial culture. By the late seventeenth century, some mid-Atlantic colonists believed that colonial debt laws and powerful urban merchants' monopolization of coin led to the appropriation of debtors' land and labor. Assembly emissions of bills of credit in New York and Pennsylvania in the 1710s and 1720s eased many debtors' burdens, but the creation of provincial paper monies enhanced rather than diminished money's importance as an object of social and political controversy in the region. By the middle of the eighteenth century, supporters of paper money believed that bills of credit uniquely embodied liberty, possessing the power to maintain ordinary inhabitants' independence. Monetary scarcity, by contrast, portended dispossession and bondage. This article analyzes the petitions, pamphlets, editorials, broadsides, and crowd actions that contributed to the creation of a distinctive culture of money in the mid-Atlantic between the 1670 s and 1760 s.
\end{abstract}

In 1764, inhabitants of Chester County, Pennsylvania, sent a petition to colonial representatives concerning "a very interesting Subject." That subject was the absence of a sufficient medium of exchange in the colony, a shortage

Bilkent University, the University of Minnesota's Center for Early Modern History, and a William Reese Company Fellowship from Minnesota's James Ford Bell Library provided support for this article. Participants of the University of Minnesota's Atlantic History Workshop in the spring of 2017 read an early draft, and comments from Jon Butler, Katherine Gerbner, and Kirsten Fischer pushed the article in the right direction. I also wish to thank the editors and anonymous readers at Early American Studies for their enormously helpful critiques and suggestions during the revision process. 
that created serious hardship for the majority of the province's people. The petition began by reminding assemblymen that for many years after settlement, inhabitants had been forced to carry on trade through commutation and barter because there was little specie in the colony. Particular suffering had befallen the "industrious Poor," who because of monetary scarcity were often at "the Mercy of those few Persons who stood possessed of the principal Part of the Gold and Silver in the Colony."To relieve the people's economic difficulties, the legislature had (beginning in the 1720s) periodically issued paper monies that creditors were required to accept as legal tender. By this "excellent Policy," inhabitants repaid debts and undertook important agricultural and other improvements. ${ }^{1}$

Now, however, the petitioners claimed that population growth and a growing dependence on British imports had led to substantial indebtedness to England, forcing local merchants to send all available specie across the Atlantic. The current absence of provincial bills of credit like those formerly issued by a loan office-which, petitioners stressed, could not be remitted to England, and whose local permanency had been essential in rescuing indebted merchants, farmers, and mechanics from economic ruin-greatly aggravated the problem, resulting in the daily seizures of defaulters' estates and forcing whole families onto public relief. Petitioners also informed representatives that they knew Parliament had recently prohibited the colonies from emitting paper monies to repay debts in England (a reference to the Currency Act of 1764), but they were convinced that if the Pennsylvania legislature would issue bills of credit, then colonists would discharge all local contracts with the paper "with the utmost Chearfulness."

In recent years, historians have challenged a traditional narrative that economic modernization followed the issuance of paper monies in England and America beginning in the 1690s. Scholars have instead emphasized the centrality of political contestation, legal change, and metropolitan and colonial state formation in the creation of paper instruments of exchange in the early modern era. ${ }^{3}$ Although recent analyses avoid a Whiggish story of

1. Petition of divers of the Inhabitants of the County of Chester, To the Honourable Representatives of the Freemen of the Province of Pennsylvania, in General Assembly met (Philadelphia, 1764).

2. Petition of divers Inhabitants.

3. Christine Desan, Making Money: Coin, Currency, and the Coming of Capitalism (New York: Oxford University Press, 2014); Claire Priest, "Currency Policies and Legal Development in Colonial New England," Yale Law Journal 110, no. 8 (June 2001): 1303-1405; Claire Priest, "Creating an American Property Law: Alienability and Its Limits in American History," Harvard Law Review 120, no. 2 (December 
inevitable monetary progress in favor of political contingency and the agency of historical actors, the sociocultural dynamics of debt and currency remain comparatively unexamined. In 1990, Daniel Vickers posited that social conflict in early America centered not on issues of markets and property rights, but rather on the agencies of power that organized the actual economy-specifically, the instrumentality of credit. ${ }^{4}$ More recently, historians have argued for the reinvigoration of the concept of class in understanding early American society, emphasizing economic power relations and the highly unequal access to resources that defined early America and the Atlantic world. ${ }^{5}$ Despite the suggestive propositions of Vickers and historians of class, scholars interested in social and economic change in prerevolutionary British America have largely neglected credit's instrumentality,

2006): 385-458; Katie A. Moore, "The Blood that Nourishes the Body Politic: The Origins of Paper Money in Early America," Early American Studies 17, no. 1 (Winter 2009): 1-36; Margaret Ellen Newell, From Dependence to Independence: Economic Revolution in Colonial New England (Ithaca: Cornell University Press, 1998). Farley Grubb's work on paper money remains essential, but is largely concerned with the later eighteenth century. Older works include Richard A. Lester, "Currency Issues to Overcome Depressions in Pennsylvania, 1723 and 1729," Journal of Political Economy 46, no. 3 (June 1938): 324-75; Curtis Putnam Nettels, Money Supply of the American Colonies before 1720 (Madison: University of Wisconsin Press, 1934); Roger W. Weiss, "The Issue of Paper Money in the American Colonies, 1720-1774," Journal of Economic History 30, no. 4 (December 1970): 770-84; Leslie V. Brock, The Currency of the American Colonies, 1700-1764: A Study in Colonial Finance and Imperial Relations (New York: Arno Press, 1975); John J. McCusker, Money and Exchange in Europe and America, 1600-1775: A Handbook (Chapel Hill: University of North Carolina Press, 1978); and Thomas Purvis, Proprietors, Patronage, and Paper Money: Legislative Politics in New Jersey, 1703-1776 (New Brunswick, N.J.: Rutgers University Press, 1986).

4. Vickers, concerned with rural New England, also suggested that conflicts over currency and demands for debtor relief in early America may have had something in common with food riots in England, a speculation taken up in the last section in this article. Daniel Vickers, "Competency and Competition: Economic Culture in Early America," William and Mary Quarterly 47, no. 1 (January 1990): 3-29, esp. 20-21. See also Daniel Vickers, Farmers and Fishermen: Two Centuries of Work in Essex County, Massachusetts, 1630-1850 (Chapel Hill: University of North Carolina Press, 1994); and Daniel Vickers, "Errors Expected: The Culture of Credit in Rural New England, 1750-1800," Economic History Review 63, no. 4 (November 2010): 1032-57.

5. Billy G. Smith and Simon Middleton, "Introduction," in Billy G. Smith and Simon Middleton, eds., Class Matters: Early North America and the Atlantic World (Philadelphia: University of Pennsylvania Press, 2008), 1-15; Seth Rockman, "The Contours of Class in the Early Republican City," Labor: Studies in Working-Class History of the Americas 1, no. 4 (Winter 2004): 91-107. 
in particular the ways in which many inhabitants experienced credit as an instrument of oppression — and conversely, paper money as liberating. ${ }^{6}$

North American colonists shared many English popular conceptions regarding money and debt. Hostility toward specie hoarding, usurious lending practices, debtor's prison, and the degradation of being forced onto public relief featured prominently in economic life on both sides of the Atlantic. ${ }^{7}$ Yet the enormous diversity of currencies used in British North America, from the commodity monies of beaver skins, wampum, and tobacco in the seventeenth century to the bills of credit issued by numerous colonies in the early eighteenth, created a novel monetary environment. In England, debtors typically directed their anger at debtor's prison and the jailers who profited from prison fees and services. ${ }^{8}$ Although imprisonment for debt was also common in the colonies, a number of

6. Neoprogressive scholars have long discussed debt and money, though they have been concerned mainly with the revolutionary and early republican periods. Important early works include Joseph Ernst, Money and Politics in America, 1755-1775: A Study in the Currency Act of 1764 and the Political Economy of Revolution (Chapel Hill: University of North Carolina Press, 1973); and Gary B. Nash, The Urban Crucible: Social Change, Political Consciousness, and the Origins of the American Revolution (Cambridge: Harvard University Press, 1979). More recent studies include Woody Holton, Forced Founders: Indians, Debtors, Slaves, and the Making of the American Revolution in Virginia (Chapel Hill: University of North Carolina Press, 1999); Woody Holton, Unruly Americans and the Origins of the Constitution (New York: New Press, 2007); Bruce Mann, Republic of Debtors: Bankruptcy in the Age of American Independence (Cambridge: Harvard University Press, 2002); and Terry Bouton, Taming Democracy: "The People," The Founders, and the Troubled Ending of the American Revolution (New York: Oxford University Press, 2007). Notable exceptions to the colonial lacuna are Simon Middleton, "Private Credit in Eighteenth-Century New York City: The Mayor's Court Papers, 1681-1776," Journal of Early American History 2, no. 2 (January 2012): 150-77; and Daniel Johnson, “What Must Poor People Do?': Economic Protest and Plebeian Culture in Philadelphia, 1682-1754," Pennsylvania History: A Journal of Mid-Atlantic Studies 79, no. 2 (Spring 2012): 117-53.

7. On England, see Craig Muldrew, The Economy of Obligation: The Culture of Credit and Social Relations in Early Modern England (New York: Palgrave Macmillan, 1998); Craig Muldrew, “'Hard food for Midas': Cash and Its Social Value in Early Modern England,” Past E $\mathcal{F}^{2}$ Present 170, no. 1 (February 2001): 78-120; Deborah Valenze, The Social Life of Money in the English Past (New York: Cambridge University Press, 2006); Alexandra Shepard, Accounting for Oneself: Worth, Status, and the Social Order in Early Modern England (New York: Oxford University Press, 2015).

8. Philip Woodfine, "Debtors, Prisons, and Petitions in Eighteenth-Century England," Eighteenth-Century Life 30, no. 2 (Spring 2006): 1-31; Jerry White, "Pain and Degradation in Georgian London: Life in the Marshalsea Prison," History Workshop Journal 68, no. 1 (Autumn 2009): 69-98. 
colonial governments passed laws in the seventeenth century allowing the seizure of land in addition to moveable property for default; those without property could even be forced into servitude to repay debts. ${ }^{9}$

Whereas politics throughout British America often hinged on the issue of money, only in the mid-Atlantic colonies of New York and Pennsylvania did the specter of land dispossession and forced labor for default infuse popular politics and culture well into the eighteenth century. ${ }^{10}$ In the 1670 s and 1680 s, currency scarcity together with debt laws shaped mid-Atlantic social relations and laid the foundation for a belief in monetary and credit manipulations that favored creditors. Ordinary colonists' suspicions around urban merchant practices were reinforced in the early eighteenth century, when inhabitants' complaints over monetary dearth fused with popular hostility to incarceration for debt and forced labor as a form of repayment. By this time colonists had formulated a unique narrative of dispossession, according to which urban merchants appropriated local money in order to subjugate others through credit. ${ }^{11}$

Conversely, many inhabitants saw paper money-which was first emitted in New York in 1709 and in Pennsylvania in 1723-as embodying liberty. The establishment of second, unofficial printers in Philadelphia and New York City in the 1720s and 1730s enabled supporters of bills of credit to place the debtor dispossession theory before the public in print. Some authors challenged conventional ideas regarding the intrinsic value of

9. On the novelty of land seizure for debt in Massachusetts, see Priest, "Creating an American Property Law," 408-16. On land's immunity from seizure in England, see Jay Cohen, "The History of Imprisonment for Debt and its Relation to the Development of Discharge for Bankruptcy," Journal of Legal History 3, no. 2 (1982): 154.

10. Whereas in the early eighteenth century, New England writers (the vast majority of tracts on money in the colonies were published in Boston) criticized the practice of purchasing mortgaged lands at less than their real value, the link between paper money and bondage that developed in the mid-Atlantic exists nowhere in New England's pamphlet literature. See for example John Colman, The Distressed State of the Town of Boston (Boston, 1720), 2, 11, 14.

11. Ethnic and cultural tensions were an additional feature distinguishing the mid-Atlantic in the late seventeenth- and early eighteenth-century mid-Atlanticin New York between Dutch-descended inhabitants and English rulers and AngloDutch merchants, and in Pennsylvania between Quaker merchants and authorities and non-Quaker commoners. Although these tensions may have played a role in the conflicts discussed herein, I have found no evidence of hostility based on a supposed relationship between wealth and ethnicity or religion. 
precious metals in favor of paper money and a labor theory of value. ${ }^{12}$ In the middle of the eighteenth century, many townspeople believed that urban merchants planned to further expand their economic power by devaluing the English copper halfpence. Crowd actions over devaluation in 1741 in Philadelphia and 1754 in New York-the only ones of their kind in British America-demonstrated how alterations in the value of small change impacted everyday life. At the same time, the press's dismissive characterization of these demonstrations as lower-sort mob actions suggests the limits of monetary radicalism, including among some supporters of paper money.

Free colonists of all ranks experienced indebtedness. But the narrative of dispossession's force as a cultural and political flashpoint lay in its representation of common people as the primary victims of economic predation. Many debtors saw credit's instrumentality in depriving laboring people without money of independence. Defaulters' experience of unfreedom was, moreover, accentuated in a region in which between 5 and 20 percent of the population was enslaved, and where statutes increasingly associated legal status with race. ${ }^{13}$ Support for paper money and a producerist ideology, according to which independent colonists' socially useful labor deserved just recompense, reinforced one another in the colonial mid-Atlantic. ${ }^{14}$ Debtors and their advocates applied a discourse of custom and fair dealing to allegedly tyrannical creditors and merchant innovators who monopolized

12. John Locke held both to a labor theory of value and a belief in the intrinsic value of specie, a position that allowed him to be appropriated by virtually all writers on money in England and the colonies. For the seventeenth-century English debate, see Joyce Oldham Appleby, Economic Thought and Ideology in Seventeenth-Century England (Princeton: Princeton University Press, 1978).

13. Enslaved people constituted approximately 5 percent of the population in Pennsylvania and 15 percent of the population in New York. These figures were considerably higher in Philadelphia (10-15 percent) and New York City (15-20 percent). Graham Russell Hodges, Root and Branch: African Americans in New York and East Jersey, 1613-1863 (Chapel Hill: University of North Carolina Press, 1999); Sharon V. Salinger, To Serve Well and Faithfully: Labor and Indentured Servants in Pennsylvania, 1682-1800 (New York: Cambridge University Press, 1987); Gary B. Nash and Jean R. Soderlund, Freedom by Degrees: Emancipation in Pennsylvania and Its Aftermath (New York: Oxford University Press, 1991); Christopher Tomlins, Freedom Bound: Law, Labor, and Civic Identity in Colonizing English America, 1580-1865 (New York: Cambridge University Press, 2010).

14. On the small producer tradition, see Ronald Schultz, The Republic of Labor: Philadelphia Artisans and the Politics of Class, 1720-1830 (New York: Oxford University Press, 1993), 4-7. 
local currency. Petitions, pamphlets, editorials, broadsides, and crowd actions involving credit and currency incorporated a language of freedom and enslavement to craft a distinctive culture of money in the colonial midAtlantic between the 1670s and 1750s.

\section{CURRENCY, DEBT, AND LAW IN THE}

\section{SEVENTEENTH-CENTURY MID-ATLANTIC}

A dearth of money in a commercializing England in the sixteenth and seventeenth centuries encouraged new ideas and practices regarding exchange and the social function of money. While the English population nearly doubled to more than five million between 1520 and 1650, and the expansion of agrarian capitalism and the growth of towns created new demands for a national medium of exchange, the state remained committed to a strong (or hard) monetary policy. ${ }^{15}$ People compensated for the shortage of money in a variety of ways, most importantly through the creation of credit networks that redefined relationships of reciprocity, trust, and obligation. ${ }^{16}$ Additionally, extralegal strategies to deal with the currency shortage included the creation of tokens and coins in localities throughout England. By the 1660s, for example, an estimated 3,543 tokeners existed in the city of London, in Westminster, and in the suburbs of London. ${ }^{17}$ Counterfeited and clipped coins, however, were more important to exchange than local tokens. Although Parliament made coining high treason in the sixteenth century, many felt that using counterfeited or clipped coins was legitimate as long as the national

15. A strong (or hard) money is one of high value relative to competing currencies. Strong currencies can have high value and lead to low or stable prices, but can restrain growth; a weak or soft currency can lead to growth, but runs the risk of inflation. In medieval and early modern Europe, people of wealth tended to favor a strong currency, whereas commoners concerned with an abundant supply of money favored a weak currency. Desan, Making Money, 153-60; Nicholas Mayhew, "Wages and Currency: The Case in Britain up to c. 1600," in Jan Lucassen, ed., Wages and Currency: Global Comparisons from Antiquity to the Twentieth Century (Bern, Switzerland: Peter Lang, 2007), 211-20. On social change in England, see Keith Wrightson, Earthly Necessities: Economic Lives in Early Modern Britain (New Haven: Yale University Press, 2000), part 1. On monetary scarcity and wages, see Craig Muldrew, "Wages and the Problem of Monetary Scarcity in Early Modern England," in Lucassen, Wages and Currency, 391-410.

16. Muldrew, “'Hard food for Midas," 163-83; Muldrew, Economy of Obligation, part 2 .

17. Valenze, Social Life of Money, 37-38; Desan, Making Money, 209; Muldrew, Economy of Obligation, 54. 
mint failed to produce enough money, and clipped coins were exchanged at face value. ${ }^{18}$

Credit relations founded on trust were somewhat successful in compensating for the cash scarcity, but the loss of freedom that often accompanied default pervaded English society and culture. Debt litigation grew dramatically in the late sixteenth century, and creditors increasingly used the courts to have defaulters imprisoned. Moralists warned against usury and reminded creditors that the reduction of debtors to slavery in ancient Rome had led to popular rebellions and the abolition of forced labor for debt. ${ }^{19}$ Meanwhile, the conditional (or penal) bond that had existed for centuries assumed new uses, including for debt. Promissory notes, or bills obligatory, became new legal instruments that pledged personal property in case of default. ${ }^{20}$ The indenture bond, in which a debtor's body served as a surety

18. Clipping coin involved the cutting or shaving off a slice of the edge of silver shillings and half crowns and then flattening and melting down the shavings for the silver, which was often exported and sold abroad. Malcolm Gaskill, Crime and Mentalities in Early Modern England (New York: Cambridge University Press, 2000), 126, 131-32; Carl Wennerlind, Casualties of Credit: The English Financial Revolution, 1620-1720 (Cambridge: Harvard University Press, 2011), 129; Anna Field, "Coining Offences in England and Wales, c. 1675-1750: The Practical and the Personal," Cultural and Social History 15, no. 2 (May 2018): 177-96.

19. A General Discovrse Against the damnable sect of Vsurers (London, 1578), 6, 7, 13-15. On debtor rebellions in ancient Rome, see P. A. Brunt, Social Conflicts in the Roman Republic (New York: Norton, 1972), 56-58. At the turn of the eighteenth century, the English agricultural writer Timothy Nourse argued that the customary seven-year system of apprenticeship was a legacy of the ancient Hebrew jubilee, when after seven years of service, poor debtors were to be treated as "hired Servants or Sojourners." Nourse, Campania Fclix; or, A Discourse of the Benefits and Improvements of Husbandry (London, 1700), 185. In the nineteenth century, Karl Marx suggested that class struggle in the ancient world primarily took the form of a contest between debtors and creditors, though this historic conflict ended with the emergence of the money form (and the defeat of debtors) in the Middle Ages. In the same passage, he also repeated the notion that plebeian debtors were ruined by creditors and replaced by slaves in Rome. Karl Marx, Capital: A Critique of Political Economy, vol. 1, trans. Ben Fowkes (New York: Penguin, 1976), 233.

20. Christopher W. Brooks, Law, Politics and Society in Early Modern England (New York: Cambridge University Press, 2008), 310-11; Tim Stretton, "Written Obligations, Litigation and Neighbourliness, 1580-1680," in Steve Hindle, Alexandra Shepard, and John Walter, eds., Remaking English Society: Social Relations and Social Change in Early Modern England (Woodbridge, U.K.: Boydell Press, 2013), 191-93. A new concern with debt and money and the morality of its uses was evident in English drama in the works of Edward Hake, Thomas Dekker, Christopher 
against future loss, became central to the creation of a labor force in England's American colonies, even as servant reports and ballads conveyed the "inhumane" treatments awaiting those bound for the Americas. ${ }^{21}$ Published petitions protested against the slavery of debtor's prison during the interregnum of the 1640s and 1650s, and remonstrations against incarceration for debt appeared in print throughout the seventeenth century. ${ }^{22}$

The loss of freedom following default would also shape society and culture in England's American colonies. Yet while the English state extended its strong money policy to the Americas, monetary scarcity combined with colonists' desire for labor conditioned colonial debt laws in ways that departed substantially from those of the metropole. In the 1640s and 1650s, Maryland, Barbados, Jamaica, and a number of New England colonies passed laws allowing the attachment of debtors (or their servants) for

Marlowe, Ben Jonson, and William Shakespeare. Muldrew, “'Hard food for Midas,” 113-17; Amanda Bailey, Of Bondage: Debt, Property, and Personhood in Early Modern England (Philadelphia: University of Pennsylvania Press, 2013).

21. In 1649, William Bullock complained, "it hath beene a constant report amongst the ordinarie sort of people, That all those servants who are sent to Virginia, are sold as slaves." William Bullock, Virginia Impartially examined, and left to publick view, to be considered by all Iudicious and honest men (London, 1649), 13-14. For servant claims of "inhuman" treatment, see Kenneth Morgan, Slavery and Servitude in North America, 1607-1800 (Edinburgh, U.K.: Edinburgh University Press, 2000), 21; Hilary McD. Beckles, White Servitude and Black Slavery in Barbados, 1627-1715 (Knoxville: University of Tennessee Press, 1989), 91; and James Revel, “The Poor Unhappy Transported Felon's Sorrowful Account of His Fourteen Years Transportation at Virginia in America," Virginia Magazine of History and Biography 56, no. 2 (April 1948): 192.

22. The Humble Remonstrance and Complaint of many Thousands of Poore Distressed Prisoners in the Prisons in and about the Citie of London committed for debt and other uncapitall Offences ... presented to the consideration of the High Court of Parliament (London, 1643); [Richard Overton and William Walwyn], "A Remonstrance of Many Thousand Citizens" (London, 1646), in Andrew Sharp, ed., The English Levellers (New York: Cambridge University Press, 1998), 47; Englands Dolefull Lamentation; or, The cry of the oppressed and enslaved Commons of England (London, 1647); $A$ brief dolorous Remonstrance; or, The pittiful Complaint, Outcry, and Request of poor destroyed Prisoners for Debt, unto all compassionate free-born Englishmen (London, 1648); A Pitiful Remonstrance; or just Complaint made to all Free-born true-hearted Englishmen, sensible of the Kingdoms miserable Slavery (London, 1648); Nerwgates Remonstrance to his Excellency the Lord Gen: Cromwel [... (London, 1653); An Humble Representation upon the Perpetual Imprisonment of Insolvent Debtors (London, 1687); [Moses Pitt], The Cry of the Oppressed: Being a True and Tragical Account of the Unparallel'd Sufferings of Multitudes of poor Imprisoned Debtors (London, 1691). 
the recovery of debts. ${ }^{23}$ The prominence of labor service for default is impossible to quantify, but anecdotal evidence indicates that forcing debtors into servitude became a distinguishing feature of the English colonies by the 1670s. ${ }^{24}$ Alexander Exquemelin, a former French West India Company employee-turned-pirate, wrote in his best-selling Bucaniers of America that an especially "rigorous" practice among the English was the selling of men who owed above twenty-five shillings for between six and eight months. In contrast to pirates, who were very "liberal and free" with those of their own kind who fell into economic difficulties, in Jamaica the English "do easily sell one another for debt." ${ }^{25}$

The Restoration colonies of New York and Pennsylvania followed earlier colonial precedents regarding debt repayment. Though for the most part the Duke of York's Laws for the Government of the Colony of New-York concerning debt followed English practice, New York borrowed from a 1656 New Haven, Connecticut, statute in allowing propertyless defaulters to satisfy debts "by service, if the Creditor so require, as also the charge of his arrest and imprisonment." ${ }^{26}$ In 1683, Pennsylvania assemblymen used this same language, although Pennsylvania lawmakers' desire to secure a labor force in the new colony led them to exempt servants ("white or black") from seizure for default, as bound laborers constituted many settlers' principal "means of Livelyhood." ${ }^{77}$ Five years later, in another major departure from

23. Richard B. Morris, Government and Labor in Early America (New York: Harper \& Row, 1965), 355-56. Though recent works have acknowledged the development of a trade in servants in the seventeenth century, the centrality of the debtorcreditor relation to the practice has gone unnoticed. See for example Simon Newman, A New World of Labor: The Development of Plantation Slavery in the British Atlantic (Philadelphia: University of Pennsylvania Press, 2013); Tomlins, Freedom Bound.

24. Legal rulings do not indicate whether defaulters were assigned to labor, suggesting that such cases were rendered informally.

25. Alexander O. Exquemelin, Bucaniers of America; or, a True Account of the Most Remarkable Assaults Committed of late Years upon the Coasts of the West-Indies (London, 1684), 38, 43-44. On Exquemelin's English reception, see Mark G. Hanna, Pirate Nests and the Rise of the British Empire, 1570-1740 (Chapel Hill: University of North Carolina Press, 2015), 138-41, 162-66.

26. Charles Z. Lincoln et al., eds., The Colonial Laws of New York from the Year 1664 to the Revolution, 5 vols. (Albany: James B. Lyon, 1894), 1:14, (hereafter cited as New York Colonial Laws); Charles J. Hoadly, ed., Records of the Colony or Jurisdiction of New Haven, from May, 1653, to the Union (Hartford, Conn.: Case, Lockwood and Co., 1858), 593.

27. James T. Mitchell et al., eds., Statutes at Large of Pennsylvania from 1682 to 1801, 18 vols. (Harrisburg, Pa.: State Printer, 1896-1919), 1:63-64, 65 (hereafter cited as Pennsylvania Statutes); Staughton George et al., eds., Charter to William 
English legal practice, the Pennsylvania assembly declared that land and homes were liable to seizure and sale one year after a legal ruling against a debtor. $^{28}$

Debtors expressed their resentment of creditors' lending practices not long after the English conquest of New Netherland in 1664 (which they renamed New York City after the Duke of York). By the 1670s, a New York City Anglo-Dutch merchant oligarchy allied to Governor Edmund Andros used its monopoly over the local economy to enslave local producers, according to Jasper Danckaerts, an itinerant Friesland Labadist. ${ }^{29}$ Urban artisans informed Danckaerts that town merchants marked up the price of imported goods 100 percent or more, and since there was no money in circulation, common farmers had to pay creditors in grain. Producers and small merchants alike suffered in turn from low grain prices caused by Andros's prohibition on the local distillation of spirituous liquors. As grain prices fell, Andros's circle of traders with West Indian connections further enriched themselves as the price of imported Caribbean rum increased. Scarce money and the monopolization of trade created a situation in which "poor farmers" had "to work for nothing, all their sweat and labor going with usury into the pockets of the tradesmen." In New York, Danckaerts reported, it was considered "a great treasure and liberty, not to be indebted to the merchants, for anyone who is will never be able to pay them." ${ }^{30}$

Penn, and Laws of the Province of Pennsylvania, passed between the Years 1682 and 1700 (Harrisburg: Lane S. Hart, State Printer, 1879), 152. The exemption of servants from seizure may have been a reference to laws in Maryland and the West Indies (from whence a number of Quaker settlers emigrated in the 1680s) that allowed the exchange of laborers for debt. In 1686 New Jersey also made provision for the satisfaction of debt through service after three months of imprisonment. John Hood, Index of Colonial and State Laws of New Jersey, between the Years 1663 and 1903 Inclusive (Camden, N.J.: Sinnickson Chew \& Sons Co., 1905), 21.

28. Pennsylvania Statutes, 1:133. Pennsylvania's prohibition of the taking of unfree workers and its allowance of land seizure for debt was reversed in mainland colonies dependent on slavery, where creditors could claim moveable goods and slaves, but not land. Like Pennsylvania, New England statutes in the late seventeenth and early eighteenth centuries did allow creditors to take freeholds to satisfy debts. Priest, "Creating an American Property Law," 413-21.

29. Danckaerts met with a number of colonists after arriving in the mid-Atlantic in search of a location to establish a settlement for Labadists, a pietist sect from Friesland in the Netherlands. See Bartlett B. James's introduction to Jasper Danckaerts, Journal of Jasper Danckaerts, 1679-1680, eds. Bartlett Burleigh James and J. Franklin Jameson (New York: Charles Scribner's Sons, 1913), xv-xxv.

30. Danckaerts, Journal of Jasper Danckaerts, 245-46; Simon Middleton, From Privileges to Rights: Work and Politics in Colonial New York City (Philadelphia: 
Pennsylvania's lieutenant governor John Blackwell made similar observations a decade later. Blackwell, a Cromwellian military official during the protectorate in the 1650s, had moved to New England to speculate in land after the revocation of his Irish properties at the Restoration. Historians have noted the inevitable animosities that arose between the Puritan soldier and members of the pacifist Religious Society of Friends (commonly called the Quakers) after his arrival in Philadelphia in 1688. Few, however, have commented on Blackwell's trenchant criticisms of Pennsylvania's economic practices. ${ }^{31}$ While in Massachusetts, Blackwell recognized that the absence of a medium of exchange limited trade and economic development; in London in 1686, he anonymously published a plan for the creation of a land bank in New England. ${ }^{32}$ The monetary chaos he found in Philadelphia, however, confounded Blackwell's vision of an orderly and prosperous colonial system of trade. Particularly striking was the cost of imported commodities: Pennsylvanians paid four shillings for goods costing twelve pence in London (a 400 percent markup) even when they could find cash, which was rare. Indeed, Blackwell claimed that he could live better in London at half the cost. Prices in Philadelphia were double what they were even in Boston, not just for luxuries, but everyday goods like linen, woolens, hats, and other necessities as well. ${ }^{33}$

University of Pennsylvania Press, 2006), 81-82. Confirmation for the cost of commodities in the city was provided by the English clergyman John Miller, who noted in 1695 that English imports yielded between 100 and 400 percent profit. John Miller, A Description of the Province and City of New-York: With Plans of the City and Several Forts as they existed in the Year 1695, ed. John Gilmary Shea (New York: William Gowans, 1862), 35.

31. Gary B. Nash, Quakers and Politics: Pennsylvania, 1681-1726 (Princeton: Princeton University Press, 1968), 122-23; Mary Maples Dunn and Richard S. Dunn, "The Founding, 1681-1701," in Russell F. Weigley et al., eds., Philadelphia: A 300-Year History (New York: W. W. Norton, 1982), 22.

32. [John Blackwell], "A Model for Erecting a Bank of Credit, etc. (London, 1688)," in Andrew McFarland Davis, ed., Colonial Currency Reprints, 1682-1751, vol. 1 (Boston: Prince Society, 1910), 154-88. Blackwell also contributed to monetary debates in London in the 1690s. John Blackwell, An essay towards carrying on the present war with France [... . (London, 1695).

33. "Original Letters and Documents," Pennsylvania Magazine of History and Biography 6, no. 3 (1882): 363-64; Joseph Dorfman, "Captain John Blackwell: A Bibliographical Note," Pennsylvania Magazine of History and Biography 69, no. 3 (July 1945): 233-37; Johnson, "What Must Poor People do?," 122. On Blackwell's personal history, see Nicholas Wainwright, "Governor John Blackwell," Pennsylvania Magazine of History and Biography 74, no. 4 (October 1950): 457-72. 
Like Danckaerts in New York, Blackwell saw an urban merchant faction in Philadelphia using an environment of monetary scarcity to exploit people in the town and its hinterland. For Blackwell, however, the roots of the problem lay not solely in local traders' avariciousness, but also in Pennsylvania's general economic and social disorder. Blackwell complained in a letter to William Penn that by raising the value of local currency to double its intrinsique value (along with the local population's willingness to pass clipped coins), colonists forced importers to double the price of their goods from England. By the time commodities reached shopkeepers and retailers after paying advances, prices were 300 to 400 percent higher. Whereas Danckaerts directed his criticism at the New York City oligarchy, Blackwell found the exorbitant wages commanded by free laborers equally responsible for Pennsylvania's economic problems. Blackwell gave the example of Philadelphia sawyers, who obtained three pounds per thousand feet of pine boards. Boston sawyers, by contrast, earned between twenty and twenty-five shillings for the same work, almost three times less than their counterparts on the Delaware River. Workers' wages consumed traders' profits in Philadelphia, according to the lieutenant governor, and a variety of deviations from metropolitan norms perpetuated economic disorder in the mid-Atlantic. ${ }^{34}$

Though some Philadelphia artisans could demand substantial wages, the continuing lack of cash in the colony created serious difficulties for many. In 1690, the Pennsylvania assembly passed a statute allowing justices of the peace to informally determine suits under forty shillings in an attempt to make it easier for creditors to collect small debts. ${ }^{35}$ Fifteen years later, the act was renewed, as was the law allowing land seizure for debt and the requirement that propertyless debtors pay by servitude. Legislators modified the latter act, however, which suggests the frequency of the practice as well as the resentments it engendered. Debtors were not to labor in servitude

34. Dorfman, "Captain John Blackwell," 237. Pennsylvania legislators considered placing a ceiling on laborers' wages at the founding, but ultimately decided that "every Man may agree with his Artificer to his best Advantage." Samuel Hazard et al., eds., Pennsylvania Archives, 8th series (Harrisburg, Pa.: J. Severns \& Co., 1852) 1:9-10. In 1691, assemblymen in New York similarly discussed a bill to regulate the "Extravagancy of tradesmen and labourers wages that work by the day," though they too decided against implementing wage regulations. E. B. O'Callaghan, ed., Journal of the Legislative Council of the Colony of New-York, 2 vols. (Albany: Weed, Parsons and Co., 1861), $1: 5$.

35. Pennsylvania Statutes, 1:141. 
for more than seven years if unmarried and under fifty-three years old, or for more than five years if married and under forty-six. ${ }^{36}$ Norms regarding terms of labor for indentured servants had been adapted to defaulters with no property, and at least some Pennsylvanians who were advanced in age and with families labored in servitude for years to repay debts.

\section{DEBT, DEBTOR'S PRISON, AND WORK}

Statutes at the turn of the eighteenth century reflected the centrality of credit to the mid-Atlantic economy. Access to credit was essential to economic survival throughout the colonies, and virtually all free people-men and women, merchants and farmers, skilled craftsmen and day laborerswere lenders as well as borrowers. ${ }^{37}$ Laws that many inhabitants believed favored creditors, however, in conjunction with debtors' precarious access to cash, showed how credit worked as a source of power and dispossession. Although debt relations were ubiquitous, from the borrowers' perspective, the legal condition of indebtedness often served distinct interests.

A form of bondage underpinned the formal debt relation, since borrowers bound themselves to lenders for a specified period until they repaid their loans. In the early 1700s, transatlantic traders like the Philadelphia merchants Thomas Callowhill and Jeffrey Pinnoll, originally of Bristol, bound themselves to the draper John Hall and the merchant Thomas Moss for the enormous sum of sixteen hundred pounds. More commonly, loans amounted to the comparatively modest (though far from insubstantial) sums of fifty or sixty pounds borrowed by artisans like the skinner Thomas Davis, the baker Abraham Roe, and the cooper Thomas Shelley. ${ }^{38}$ As in England, cash-strapped employers made legal agreements to repay work later. In early 1714, the Philadelphia bolter Leeson Loflus promised to pay the miller John Holme eighteen pounds by the end of the following March for

36. Pennsylvania Statutes, 2:249-51.

37. On New York City artisans and credit in the early eighteenth century, see Middleton, Privileges to Rights, 102-13. On informal credit networks organized communally in New England, see Vickers, "Errors Expected,"1046, 1053-54. Credit networks in the substantial informal economies involving enslaved people and poor colonists - especially unmarried women - in New York City and Philadelphia generally went unrecorded unless they involved counterfeited currency. See Serena R. Zabin, Dangerous Economies: Status and Commerce in Imperial Nerw York (Philadelphia: University of Pennsylvania Press, 2009).

38. Records of Philadelphia County, 1671-1855, collection 1014, box 1, folder 7 (Davis), folder 8 (Roe, Shelley, Callowhill and Pinnoll), Historical Society of Pennsylvania (hereafter cited as HSP). 
grinding wheat. ${ }^{39}$ When poor debtors like the laborer Joseph Stevenson or unmarried women like one Sarah Radcliffe were unable to repay loans, it is likely they were bound to some form of labor to satisfy creditors. ${ }^{40}$

Although wealthy urban merchants stood atop mid-Atlantic society in affluence and access to money by the late seventeenth century, artisans were crucial to the circulation of credit in the region. ${ }^{41}$ The bricklayer Thomas Sisom lent between $£ 10$ and $£ 240$ to other tradesmen and laborers; at his death in 1715, Sisom possessed thousands of acres in Pennsylvania in addition to numerous homes and rental properties throughout Philadelphia. ${ }^{42}$ Silversmiths were especially important to the provision of credit. Cesar Ghiselin and Joseph Richardson received gold and silver to make spoons, buttons, and shoe buckles for urban grandees; they also frequently loaned cash to tradesmen and laborers. ${ }^{43}$ Silversmiths were also essential to local counterfeit coining operations, evident in New York and Philadelphia as early as the 1680 s. Merchants who obtained silver then passed it on to smiths to be coined. Though mid-Atlantic governments initially treated counterfeiting as a minor offense, by the 1710s offenders could be executed..$^{44}$ Lacking an official local currency, inhabitants borrowed

39. Attachment of Leeson Loflus by John Holme (1715), Philadelphia Court of Common Pleas, 1697-1732, Mitchell Collection, box 19, HSP. On England, see Muldrew, "Wages and Monetary Scarcity,"102-3.

40. Philadelphia Court of Common Pleas (1712, 1714), Mitchell Collection, box 19, HSP.

41. On mid-Atlantic merchants, see Cathy Matson, Merchants and Empire: Trading in Colonial New York (Baltimore: Johns Hopkins University Press, 1997); Frederick B. Tolles, Meeting House and Counting House: The Quaker Merchants of Colonial Philadelphia, 1682-1763 (Chapel Hill: University of North Carolina Press, 1948).

42. Last will and testament of Thomas Sisom (1715), Records of Philadelphia County, 1671-1855, collection 1014, box 1, folder 10, HSP. On Sisom's lending practices, see Records of Philadelphia County, 1671-1855, collection 1014, box 1, folders 6-9, HSP; Philadelphia Court of Common Pleas (1697-1732), Mitchell Collection, box 19, HSP.

43. Harrold E. Gillingham, "Cesar Ghiselin, Philadelphia's First Gold and Silversmith," Pennsylvania Magazine of History and Biography 57, no. 3 (July 1933): 244-59; Account Book of Joseph Richardson, 1733-1739, Am.9240, HSP. Ghiselin and Richardson were also, of course, in debt to substantial city merchants at the same time that they loaned money to others.

44. Samuel Hazard, ed., Minutes of the Provincial Council of Pennsylvania, from the organization to the termination of the proprietary government, 16 vols. (Philadelphia: J. Severns, 1852-53), 1:84-88 (hereafter cited as Provincial Council Minutes); Kenneth Scott, Counterfeiting in Colonial America (New York: Oxford University Press, 1957), 18-21, 24; Julius Goebel Jr. and T. Raymond Naughton, Law Enforcement in 
if possible, and readily passed Spanish pieces of eight and Boston shillings produced by local coining rings.

As in England, debtor's prison constituted the primary form of longterm incarceration in the colonies. Debtors were treated differently than other prisoners on both sides of the Atlantic. As early as 1704, New York built a separate space of confinement for debtors in the upper story of City Hall. Two decades later, however, prisoners petitioned the provincial assembly complaining that the town jail was overfilled with debtors, and that borrowers of "better Condition" remained "promiscuously Confined" alongside "Profligate" inmates and common criminals. Accordingly, the city ordered that six hundred pounds be raised for a new city jail..$^{45}$ In the late 1710 s, Philadelphia took out a voluntary subscription for construction of a new jail. Stone Prison, completed in 1723 and located at the southwest corner of Third and High streets, was comprised of two structures separating debtors from accused criminals. ${ }^{46}$

Imprisonment for debt was traditionally intended to compel payment by forcing borrowers to reveal concealed property or find allies to repay debts. By the early eighteenth century, however, some mid-Atlantic inhabitants believed that incarceration for default and forced labor were parts of a concerted plan to dispossess small borrowers. In 1705 (the same year the Pennsylvania assembly refined the colony's debt law), the recently chartered Corporation of Philadelphia raised fees for debtor's court in the county. ${ }^{47}$ In at least two petitions to Lieutenant Governor John Evans, jailed debtors

Colonial New York: A Study in Criminal Procedure, 1664-1776 (New York: Commonwealth Fund, 1944), 95, 97. The first person executed in Philadelphia after Pennsylvania's adoption of English common law punishments in 1718 was a silversmith from Antrim named Edward Hunt. American Weekly Mercury (Philadelphia), November 24, 1720. The New York assembly made counterfeiting of provincial paper money a capital offense without benefit of clergy when it first emitted bills of credit in 1709; similar calls were heard in Pennsylvania by 1727. New York Colonial Laws, 1:739; Hazard et al., Pennsylvania Archives, 8th series, 3:1807.

45. Minutes of the Common Council of the City of New York, 1675-1776 (New York: Dodd, Mead, and Co.), 3:370-71, 372 (hereafter cited as New York Common Council Minutes).

46. Minutes of the Common Council of Philadelphia, 1704-1776 (Philadelphia: Crissy \& Markley, 1847), 37, 227 (hereafter cited as Philadelphia Common Council Minutes); John Fanning Watson, Annals of Philadelphia, in the Olden Times, 3 vols. (Philadelphia: E. S. Stuart, 1887) 1:305, 357-58, 360.

47. Philadelphia Common Council Minutes, 16,19. An important power the corporation did not have was the right to levy taxes; the municipality therefore obtained revenue largely through fees and licenses. 
wondered how they were to pay new court fees, let alone repay old debts, with no money in the area. Unable to pay the fees, debtors claimed that they were held in the town jail "untill they could find a person to sell themselves unto for a Term of Years to Pay the same and Redeem their bodies to the great Ruine and Destruction of themselves and families." In petitioners' view, the court violated established custom (three shillings had been the previous fee), incarcerated impoverished inhabitants, and forced debtors or family members into servitude to redeem male heads of households. Rather than deliver petitioners "out of the Jaws of that pernicious devouring and Extravagant Court," Lieutenant Governor Evans-who, like Blackwell, was no friend of leading Philadelphia Quakers-ruled that the chartered corporation was allowed to establish its own fees for services, as was done in towns throughout England. ${ }^{48}$

Pennsylvania officials worried about local reactions to provincial debt policies when colonists received news of metropolitan reforms. Around the time the municipalities of New York and Philadelphia were building new jails to accommodate growing numbers of debtors, colonists learned of James Oglethorpe's Gaols Committee of 1729-30, a parliamentary investigation into the state of England's jails. The committee exposed horrific prison conditions, especially in London's Fleet and Marshalsea prisons. ${ }^{49}$ Conditions in colonial jails could also be life-threatening: in 1727, the Philadelphia jailer William Bidle claimed that Stone Prison inmates unable to pay fees were near starvation. ${ }^{50}$ The English prison scandal and the limited

48. "The Humble Petition of Diverse poor Inhabitants of the City and County of Philadelphia," Records of Philadelphia County, 1671-1855, collection 1014, box 1, folder 6, HSP. Though the petition is undated, it is addressed to Evans. For a second, slightly differently worded petition, see Watson, Annals of Philadelphia, 1:358. For Evans's response, see Provincial Council Minutes, 2:269. On debtors' petitions in eighteenth-century England, see Woodfine, "Debtors, Prisons, and Petitions."

49. Oglethorpe, a Tory social reformer and founder of the Georgia Colony, was led to the investigation after his friend, the architect Robert Castell, entered Fleet Prison for debt and, unable to pay fees for a better berth, died of smallpox in 1728 . White, "Pain and Degradation," 76; Woodfine, "Debtors, Prisons, and Petitions," 18. The full title of the committee's report is A Report from the Committee Appointed to Enquire into the State of the Gaols of this Kingdom: Relating to the Marshalsea Prison; and Farther Relating to the Fleet Prison (London, 1729).

50. Philadelphia Common Council Minutes, 279. A year earlier, the Quaker merchant Francis Rawle claimed that the number of debt prisoners in Pennsylvania was "beyond what was ever known in America." [Francis Rawle], A Just Rebuke to a Dialogue betwixt Simon and Timothy (Philadelphia, 1726), 16. Pennsylvania's humanitarian founding charter stated that all prisons were to be "free, as to fees, food, and 
reforms that followed made their way into the Pennsylvania provincial council's debate over a bill for debtor relief in 1730. Councilmen noted that the "publick Prints" had informed the local populace of recent English legislation for the prevention of abuses in prisons. Officials acknowledged that jailers should avoid excessive cruelty, but they also argued that "as our Circumstances differ" so greatly from those of England, care should be taken not to make the execution of justice too difficult. The delicate nature of the problem was, according to councilmen, accentuated by the "odd humours \& Tempers" so frequently displayed by those most likely to be jailed for debt. ${ }^{51}$

Seventeenth-century laws allowing labor service as a form of debt repayment stressed that this was permissible only if desired by creditors. In the early 1730s, the legislatures of both New York and Pennsylvania claimed that repayment through work was foremost an act of compassion to debtors. ${ }^{52}$ Yet when discussing the debtor relief bill, Pennsylvania authorities worried about the Crown's response to debt repayment by service. Pennsylvania councilmen claimed that in Britain, "they are wholly Strangers to Servitude as practised amongst us, or binding of Persons otherwise than as Apprentices, \& therefore none of their Acts have ever Directed Satisfaction to be made for Debts by any such means." In the colonies, by contrast, it was perfectly reasonable that "People fitt for Labour, or performing any Service by which they can earn Money, should by the same Method make Satisfaction for their just Debts." ${ }^{\text {3 }}$

Some debtors evidently did not see the repayment of debts through labor as an act of compassion. In February of 1731, the Pennsylvania assembly amended the law for insolvent debtors passed the previous year because "sundry idle and ill-disposed persons" indebted before the statute's passage "abused" creditors and took advantage of the "good intentions of the legislature" by claiming insolvency. Assemblymen were particularly troubled by evidence that unmarried people indebted for sums "which they could easily have paid by their labor" claimed insolvency instead, suggesting that legislators deemed repayment through service particularly suitable for the young and single. The amendment therefore barred those whose contracts were

lodging," a humanitarian approach to incarceration abandoned in the early eighteenth century. Provincial Council Minutes, 1:38.

51. Provincial Council Minutes, 3:377.

52. New York Colonial Laws, 2:754; Pennsylvania Statutes, 4:171.

53. The reference to people "fitt for Labour" suggests that the practice of debt labor was reserved for those accustomed to manual work. Provincial Council Minutes, 3:376. 
made before law's passage from benefitting from its provisions-except those imprisoned in public jails before August 1, 1730. Nor could anyone under forty and without children owing less than twenty pounds benefit from the act, regardless of when the contract was made. The amendment stated that such people would be subject to the statute allowing debts to be repaid by servitude. ${ }^{54}$

The most dramatic demonstration of hostility to debt bondage occurred in the context of the War of Jenkins' Ear (1739-42). After England's declaration of war against Spain in 1739, the Crown demanded money and bodies from colonial legislatures. To the pronounced annoyance of Lieutenant Governor George Thomas, an Antiguan sugar planter, Pennsylvania assemblymen refused assistance, citing Quaker opposition to arms..$^{55}$ In the spring of 1740 , Thomas read a proclamation that creatively interpreted royal instructions, and implicitly suggested to volunteers that they would be free from any labor obligations after military service was completed. ${ }^{56}$ By the summer of 1741, incensed legislators claimed that more than three hundred servants had abandoned masters in Pennsylvania; at least 188 of them (valued by masters and legislators at $£ 1,580$ ) had fled from the city and county of Philadelphia, amounting to more than 30 percent of the town's servant population. ${ }^{57}$ The controversy demonstrated the complex dynamics of race, labor, and class in the mid-Atlantic when petitioners from Chester County complained that enlistment constituted "a very hard and unequal Tax" on middling freemen who held white servants while others who were "more wealthy" possessed "no other Servants but Negroes," who obviously could not enlist. Assemblymen also noted that if their property in servants was so "precarious," they would continue to import enslaved Africans against the ostensible wishes of the Crown. ${ }^{58}$

54. Pennsylvania Statutes, 4:211-15.

55. Pennsylvania assemblymen had also resisted war funding in the 1690s and 1700s. One reason they did so in 1706 was because there was little money in the colony, with many colonists "poor, and in Debt." Hazard et al., Pennsylvania Archives, 8th series, 1:575.

56. Provincial Council Minutes, 4:395-97, esp. 396.

57. By comparison, as of June 1741, fifty-eight servants fled Chester County and nineteen left masters in Bucks County. Hazard et al., Pennsylvania Archives, 8th series, 3:2656, 2677. For population figures, see Tomlins, Freedom Bound, tables 1.9, $1.11,46,49$. Sharon Salinger claimed that close to half of the servant population fled during the war, though this is probably an overestimate. Salinger, To Serve Well and Faithfully, 59.

58. Hazard et al., Pennsylvania Archives, 8th series, 3:2574; Provincial Council Minutes, 4:437. 
Scholars have analyzed the two-year feud between Thomas and assemblymen over servant enlistment, and have emphasized the extent to which Pennsylvania legislators believed servants to be a property like any other. ${ }^{59}$ They have not noted that men laboring to pay off debts volunteered alongside indentured servants, apprentices, and freemen. Within months of Thomas's proclamation, rumors circulated among enlistees that the lieutenant governor had agreed to send servants back to their masters. In a letter to Thomas, twenty-five officers reported that troops under their command had grown "exceedingly uneasy" after hearing such rumors, some even publicly declaring that "they will never suffer themselves to be separated, and rather than be exposed to the inhumane usage of the Masters of some of them, and the Creditors of others for small Debts, they will go into some other Government where they hope to be better used and protected in His Majesty's Service." ${ }^{\prime 0}$

Enlistees' refusal to work and threats of desertion were successful, for most did not return to masters or creditors. ${ }^{61}$ Unfree workers also enlisted in large numbers during the Seven Years' War (1754-63), and it is probable that some volunteers were debt laborers. In the early 1750s, the German schoolmaster and musician Gottlieb Mittelberger noted that in Pennsylvania, the seizure of debtors' property was a regular occurrence, while propertyless debtors went to prison until someone vouched for them or "till he is sold." Mittelberger claimed that debtors owing five pounds or more were forced to labor in unfreedom for a year or longer; children, regardless of age, were sold into servitude until age twenty-one to redeem imprisoned parents. ${ }^{62}$ In language remarkably similar to that of early eighteenth-century petitioners, Mittelberger saw the treatment of debtors in an otherwise prosperous mid-Atlantic environment as evidence of a distinctive regime of unfreedom rooted in exploitative credit relations.

59. Alan Tully, William Penn's Legacy: Politics and Social Structure in Provincial Pennsylvania, 1726-1755 (Baltimore: Johns Hopkins University Press, 1977), 28; Cheesman A. Herrick, White Servitude in Pennsylvania (Philadelphia: John Joseph McVey, 1926), 125-26.

60. Provincial Council Minutes, 4:467.

61. The assembly, however, compensated masters for their lost property from a public fund that was part of an agreement to provide the Crown money. Hazard et al., Pennsylvania Archives, 8th series, 3:2673-74, 2675.

62. Mittelberger also noted that those who counterfeited Pennsylvania paper notes were executed without possibility of pardon. Carl Theo Eben, trans. Gottlieb Mittelberger's Journey to Pennsylvania in the Year 1750, and Return to Germany in the Year 1754 (Philadelphia: John Joseph McVey, 1898), 89, 91. 


\section{PAPER MONEY AND PRINT CULTURE}

Mid-Atlantic colonists devised a variety of means to deal with scarce currency and indebtedness in the late seventeenth and early eighteenth centuries. As early as the 1670s, the royal official Edward Randolph complained that colonists raised the value of local currency in an effort to attract money from abroad..$^{63}$ In 1704, Queen Anne attempted to put a stop to colonists' monetary licentiousness by issuing a proclamation prohibiting them from inflating the value of coins by more than one-third of their sterling equivalent, and setting the exchange rate of Spanish pieces of eight at six shillings. In contrast to New York, Pennsylvania legislators followed Crown instructions regarding exchange rates and resisted printing provincial bills of credit, which were first issued by Massachusetts in 1690 and soon afterward by South Carolina. ${ }^{64}$ Quaker lawmakers' resistance to paper money led to serious tensions in Philadelphia and its environs, and by the 1720s, Pennsylvania had joined New York and other colonies in issuing bills of credit. ${ }^{65}$ The formation of lively print cultures in New York City and Philadelphia during the same period led to the publication of competing ideas about the nature of money, while also giving public expression to an evolving narrative of creditor oppression.

After receiving news of Queen Anne's 1704 proclamation, colonial merchants worried that they would be at a severe disadvantage should their legislatures revalue their money according to the proclamation while other colonial governments did not. Debtors feared that the act would substantially increase their burden. Parliament ratified the proclamation in 1707; the Pennsylvania legislature followed in 1709. However, New York, like Massachusetts, ignored the act, issuing its first five thousand pounds in bills of credit the same year the Pennsylvania legislature approved the royal decree. ${ }^{66}$ Over the course of the next decade, New York issued tens of thousands of pounds in paper money while Pennsylvanians remained without a

63. See Hanna, Pirates Nests, 170-71, 349.

64. In 1690 and 1691, Massachusetts printed seven thousand pounds and forty thousand pounds in bills of credit, respectively; in 1703, South Carolina emitted six thousand pounds. Andrew McFarland Davis, "Introduction," in Colonial Currency Reprints, 21-24, 33; McCusker, Money and Exchange, 125-26. Colonial assemblies justified these early emissions by the exigencies of war against France and Spain.

65. By this time in English North America, only Virginia and Maryland, still committed to the commodity money of tobacco, had yet to print local bills of credit.

66. Like the earlier emissions of paper bills in Massachusetts and South Carolina, New York's emission in 1709 was bound up with financing war. New York Colonial Laws, 1:666-68. 
provincial currency. Sellers, creditors, and the New York treasury were required to accept the bills at face value, facilitating the payment of debts and taxes while making possible a number of urban development projects. ${ }^{67}$ Paper money and the repayment of some debts did not eradicate New Yorkers' need for credit, however. One of the projects that New York paper money helped pay for was, ironically, a new prison to house growing numbers of debtors in the city. ${ }^{68}$ While debating a new money bill in 1717 (and acknowledging that local currencies defied imperial policy), New York governor Robert Hunter stated to the Board of Trade: "I do affirm that this is at present the most flourishing Province in Trade \& Creditt our Money Bills are now at least, Thirty Pr Cent better than those of New England on their own Exchange, and equall to Silver all round about us." ${ }^{9}$ Though many New York merchants continued to oppose "imaginary" paper money, even imperial officials acknowledged the utility of paper bills in facilitating trade.

The Pennsylvania assembly's reluctance to issue a provincial currency, together with the Crown's monetary reform, led to recurring conflicts in Philadelphia and its vicinity. After legislators' authorization of Queen Anne's decree, a number of city landlords and creditors required payment in new proclamation money. Debtors and renters protested the change; petitioners informed legislators that the obligations of some townspeople had been usuriously raised by 33 percent (or one-third) overnight. In an apparent victory for petitioners, the assembly stipulated that contracts made prior to the statute's approval could be repaid in old exchange rates. However, Philadelphia renters complained to representatives throughout the $1710 \mathrm{~s}$ that landlords continued to exact rents in proclamation money in defiance of the law. ${ }^{70}$

67. New York Colonial Laws, 1:695-97, 737-40, 819-26, 847-48, 853-57, 938-46; New York Common Council Minutes, 2:395, 401, 413, 3:83, 113. On the use of New York bills to pay private creditors of the colony, see An Act Passed by the General Assembly of New-York (New York, 1714). See also Deborah A. Rosen, Courts and Commerce: Gender, Law, and the Market Economy in Colonial New York (Columbus: Ohio State University Press, 1997), part 1. On the high politics of finance, see Patricia U. Bonomi, A Factious People: Politics and Society in Colonial New York (New York: Columbia University Press), 82-87.

68. New York Common Council Minutes, 3:372.

69. John Romeyn Brodhead et al., eds., Documents Relative to the Colonial History of New York, 15 vols. (Albany: Weed, Parsons and Co., 1853-87), 5:516, 539.

70. Hazard et al., Pennsylvania Archives, 8th series, 2:533, 840-44, 889, 955, 1124, 1237, 1262-63, 1266, 1269, 1415; Provincial Council Minutes, 2:566. 
Pennsylvanians proposed a number of reforms to address currency difficulties between the late 1710s and early 1720s. In 1710, a group of Philadelphians requested a ban on the exportation of money from the province, the laying of a tax on imported wine, and the issuance of paper money. Over the next decade, colonists suggested raising the value of local currency, allowing agricultural produce to serve as payment for taxes, raising duties on imports (including servants and slaves), and lowering the legal interest rate from 8 to 6 percent to ease the colony's economic difficulties. ${ }^{71}$ It was only in 1723, however, in the midst of the colony's first major economic slump, that the assembly agreed to issue fifteen thousand pounds in bills of credit. Legislators found this amount insufficient, however, and agreed to print a further thirty thousand pounds at the end of the year. ${ }^{72}$

Currency remained a source of controversy throughout the decade despite the emissions, as supporters and detractors of paper money turned to the local press to express their competing views. The first work calling for provincial paper money was Francis Rawle's Some Remedies Proposed, for the Restoring the Sunk Credit of the Province of Pennsylvania, anonymously published by the printer Andrew Bradford in 1721. In addition to a lack of currency, a trade imbalance with England and the lapsing of bolting regulations-which according to Rawle benefitted New York, since West Indian buyers preferred New York's better-regulated and therefore higherquality flour-had contributed to Pennsylvania's economic woes. Rawle, a Philadelphia Quaker merchant (and one of the landlords involved in disputes with tenants in the 1710s), claimed in good commonwealth fashion that it was the "common People" who were most damaged by currency scarcity: without an adequate money supply, commoners' labor was not fairly rewarded and their estates were confiscated and sold due to debt. ${ }^{73}$ Though Rawle argued in measured prose for the temporary issuance of a strictly regulated paper money, the provincial council charged Bradford the following year with libeling the Pennsylvania government for publishing the pamphlet. ${ }^{74}$

Historians have examined the development of factional politics in 1720 s Philadelphia in detail, often placing Governor William Keith and the antiproprietary lawyer and politician David Lloyd in opposition to the

71. Hazard et al., Pennsylvania Archives, 8th series, 2:921-22, 1262, 1361, 1391, 1393, 1398; Pennsylvania Statutes, 3:117-21, 238-40, 338-39.

72. Pennsylvania Statutes, 3:385-88, 389-407.

73. [Francis Rawle], Some Remedies Proposed, for the Restoring the Sunk Credit of the Province of Pennsylvania [...] (Philadelphia, 1721), 4, 7.

74. Provincial Council Minutes, 3:143, 145. 
proprietary stalwarts James Logan and Isaac Norris. ${ }^{75}$ Though they have also noted that currency scarcity contributed to hostilities, money is usually demoted to epiphenomenal status in analyses of the decade's pamphlet war. ${ }^{76}$ In fact, as faction leaders traded personal insults in the local press, anonymous authors kept the money issue central to provincial politics throughout the decade-including after the breakdown of the popular Keith-Lloyd alliance. Some colonists may have known the identities of the unsigned tracts' authors, but anonymity could nonetheless provide cover for more biting criticisms and popular-radical politics. ${ }^{77}$ Indeed, the publication of short satires and allegorical dialogues focusing on currency, debt, and elite intrigue after 1725 represents an important escalation of the conflict. ${ }^{78}$ Anonymous pamphlets written in a colloquial language very different from scholarly treatises intended for the lettered signaled a radical politicization of money, as well as a departure from English pamphlet debates of the 1690s. The appearance in print of ideas that previously circulated orally also legitimated popular demands for relief, while giving public expression to the belief that men in power had historically used credit to dispossess ordinary colonists.

Philadelphia pamphlets initially focused on colonial law and sovereigntyspecifically the extent of the assembly's power. ${ }^{79}$ However, it was the publication of a dialogue between the allegorical figures of city merchant

75. Nash, Urban Crucible; Thomas Wendel, “The Keith-Lloyd Alliance: Factional and Coalition Politics in Colonial Pennsylvania," Pennsylvania Magazine of History and Biography 92, no. 3 (July 1968): 289-305.

76. Nash, Urban Crucible, 151-53; Schultz, Republic of Labor, 20-23.

77. In 1726, Rawle claimed (in another anonymous pamphlet) that printers were sworn to secrecy as to authors' identity. [Rawle], A Just Rebuke, 6. Anonymity also, of course, conventionally connoted selfless republican virtue.

78. In keeping with classical thought, dialogues had long been believed by the learned to be particularly suited to the education of common people, and an English literary tradition focused on the figure of the honest plowman can be traced to the fourteenth century, at least. The Establishment; or, A Discourse tending to the setling of the Minds of Men, about some of the chiefe Controversies of the present Times (London, 1654), dedicatory [9]; Ordelle G. Hill, The Manor, the Plowman, and the Shepherd: Agrarian Themes and Imagery in Late Medieval and Early Renaissance English Literature (Selinsgrove, Pa.: Susquehanna University Press 1993); Andrew McRae, God Speed the Plough: The Representation of Agrarian England, 1500-1660 (New York: Cambridge University Press, 1996).

79. James Logan, The Charge Delivered from the Bench to the Grand-Jury ... of Philadelphia (Philadelphia, 1723); David Lloyd, A Vindication of the Legislative Power (Philadelphia, 1725); James Logan, The Antidote, in some Remarks on a Paper of David Lloyd's (Philadelphia, 1725). 
"Robert Rich" and farmer "Roger Plowman" in 1725 by the town's new printer, the London dissenter Samuel Keimer, that set the tone for populist pro-paper arguments. ${ }^{80}$ Although Rich and Plowman agreed that hard times had returned to Pennsylvania, they differed over its causes. According to Rich, overvalued paper money had driven gold and silver from the province and had nearly ruined the colony. Plowman denied Rich's assertion of an alleged 10 percent difference between paper and precious metal values, and responded to the merchant's claim that paper lacked intrinsic value by noting that it purchased land as well as agricultural goods "as cheap as it was ever sold: And is that good for nothing?" In reality, merchants disliked paper because it allowed farmers and mechanics to repay debts, which deprived creditors of producers' land and labor. City merchants' demands to be repaid in nonexistent money was alleged to be evidence of their real desire, which was to enslave debtors: "You will have Money; but money is not to be got, neither here nor at the West-Indies, and yet nothing will satisfy you but money." Merchants, likened by Plowman to Egyptian taskmasters, kept money scarce and plunged city artisans into "a thousand Difficulties" while forcing honest farmers to give their labor "away to others"- a potent reminder of the value of work as well as the degradation of labor in the service of another. ${ }^{81}$

A satirical letter of the same year demonstrated the relationship between currency and popular politics. The author of the letter pretended to overhear a secret discussion among the Pennsylvania "Triumvirate" (the land bank trustees Logan, Norris, and Richard Hill) in a conference room in the House of Representatives. ${ }^{82}$ According to "Pedagogus Matematicus" (undoubtedly Logan), assembly promoters of the bill had failed to ask for the triumvirate's approval, evidence that confirmed the "Democracy in the People" and the placing of all in the province on a level. ${ }^{83}$ The triumvirate's "Perquisits"- court fees, or possibly bribes—and their expropriation of all

80. On Keimer and print culture in Philadelphia and New York, see James Green, "Part One: English Books and Printing in the Age of Franklin," in Hugh Amory and David D. Hall, eds., A History of the Book in America, vol. 1, The Colonial Book in the Atlantic World (Chapel Hill: University of North Carolina Press, 2007), 248-55.

81. A Dialogue between Mr. Robert Rich and Roger Plowman (Philadelphia, 1725), $1,3-4$.

82. Type and font also suggest that Keimer printed the work, a letter addressed to a "FRIEND in the Country." The Pennsylvania land bank and trustee system was established with the first paper money emission. Pennsylvania Statutes, 3:326-38.

83. Logan's well-known and ostentatious learning was a constant source of ridicule in Philadelphia, hence the comical Latin name. 
the province's "running Cash" were now at risk because of a money bill put forth by a "mobb Assembly." It was therefore necessary to smother the "Monster" of paper currency, lest the colony's "Rich Men and Merchants" be "reduced to the same Condition of that we had reduced all Tradesmen, Handy-crafts and Farmers before this Emition was thought of." ${ }^{84}$ Paper money, in this account, freed common people from a widespread condition of bondage, and grandees' opposition to bills of credit was linked to their fears of political leveling. Currency thus functioned on multiple levels, with bills of credit restoring the people's liberty while simultaneously fostering a democratic political culture.

Logan anonymously published a response to pro-paper satires later in the year. ${ }^{85}$ Though also written in a vernacular dialogic form, $A$ Dialogue Shewing what's therein to be found expressed a hard money position that disparaged bills of credit. Paper money was "imaginary Stuff," and the value of Pennsylvania currency had fallen as a result of its use. Logan connected the popular clamor for paper currency to other traditionally elitist ideas. Common people were inherently susceptible to the blandishments of demagogues, whose "clever Words" in the mid-Atlantic context included "talk of Medium of Commerce, Balance of Trade, Publick Good, Funds, Loans, Striking, Sinking, and such like." Though understanding such concepts was beyond the capacity of most colonists, currency discussions produced a culture of popular political engagement, the result of which was a pervasive lack of deference in city and colony. According to Logan, the true causes of debt and economic difficulties were the excessive consumption of alcohol, the lack of a proper work ethic, and a disorderly propensity among the laboring sort to politick in city taverns. ${ }^{86}$

Pennsylvania pamphleteers continued to debate monetary policy the following year, which was also the year in which the Keith-Lloyd coalition fractured. Scholars have emphasized ideological and political differences between the royalist governor Keith, with his supporters largely based in

84. The Triumvirate of Pennsylvania, In a Letter to a Friend in the Country (Philadelphia, 1725).

85. Type and font size suggest that this pamphlet was published by Bradford.

86. [James Logan], A Dialogue Sherwing what's therein to be found: A Motto Being Modish, for Want of Good Latin, Are Put English Quotations (Philadelphia, 1725), 12, 26-32. Perhaps unsurprisingly, A Dialogue Shewing was unable to shift public sentiment toward a hard money position-one pamphlet found nothing in Logan's tract "but a dull Recipe for a Poor Devil just got out of Servitude, how to keep himself out of Debt." [William Keith], The Observator's Trip to America, in a Dialogue Between the Observator and bis Country-man Roger (Philadelphia, 1726), 25. 
Philadelphia, and the anti-proprietary Quaker and rural-backed Lloyd, in the break in the popular party. ${ }^{87}$ There is evidence that party differences involved ideas about money and the value of labor as well. Early in 1726, Philadelphians who had "taken up Ground for a certain Term of Years upon Rent" delivered a petition to an assembly in which Lloyd served as speaker. Petitioners requested that the properties they had "improved" through their labor be used as security for another emission of bills of exchange. After a second reading and a House debate, assemblymen rejected the petition, claiming that because renters' estates were not freeholds, their properties were not a proper security for new bills.$^{88}$ For urban petitioners, much like paper money's value was determined by its usefulness, improvements arising from labor made human activity a key source of value. Landed rural legislators, however, were unwilling to go so far. When Lloyd defeated Keith for the speakership of the House later in the year, animosities toward the speaker in the city were such that Lloyd requested protection for himself and other assemblymen—not "on account of their Debts," but because "the Insults of the rude People of this City" portended physical danger for himself and his allies. ${ }^{89}$

Paper money continued to constitute the chief political issue in Philadelphia print culture at the end of the decade, well after the populist figurehead Keith had departed the colony. The 1729 pamphlet $A$ Revisal of the Intreagues of the Triumvirate again accused Logan and other officials of engrossing all the money in the province in order to bring tradesmen and farmers into their debt. Debtors were left "to the Mercy of their Tyrants," who "under pretence of Charity" purchased the homes and properties at greatly reduced rates, only to then let them out at exorbitant rents. Loan office authorities had allegedly spent the previous two years working by any means possible to prevent another paper money emission. Their ostensible purpose was to place fellow subjects in a state of "Vassalage" that could not be done without "first Suppressing the current Cash of the Province." "

A response to the Revisal repeated earlier criticisms of populist demagogues, in the process indicating how widespread the narrative of monetary monopoly and dispossession had become. "Philadelphus" claimed that the story of specie's engrossment had been told in Philadelphia as "often to

87. Wendel, "Keith-Lloyd Alliance"; Nash, Quakers and Politics.

88. Hazard et al., Pennsylvania Archives, 8th series, 2:1738, 1739.

89. Provincial Council Minutes, 3:260-61; Hazard et al., Pennsylvania Archives, 2nd series, 7:94-97; Wendel, "Keith-Lloyd Alliance," 301-2; Nash, Quakers and Politics, 334-35.

90. A Revisal of the Intreagues of the Triumvirate (Philadelphia, 1729). 
weak People" as "the Tales of the King and Queen of Fairies to Children." Also fantastic was an oft-repeated story in which a city lot and eight acres of liberty land (which consisted of eight thousand acres that Penn set aside outside the town for founding-era land purchasers) were purchased for five pounds and then annually let out for six shillings per foot in perpetuity. That the credulous believed such fanciful stories made it essential in Philadelphus's view that men of "Abilities and Circumstances"-meaning the colony's traditional Quaker elite-be elected to the assembly in the upcoming election. ${ }^{91}$

As assemblymen discussed a third paper money emission after almost four years of wrangling, disagreement threatened to migrate from the halls of the assembly and the urban public sphere to the streets of Philadelphia. Initially, pro-paper forces had called for an emission of fifty thousand pounds; when it became known that some legislators would approve only twenty-five thousand pounds, paper supporters accosted the assemblymen outside the State House. Rumors then circulated that large numbers of farmers planned to descend on Philadelphia and join with townspeople to force their demand for more money on legislators. Governor Patrick Gordon read a proclamation against rioting, and the feared uprising failed to materialize. In the aborted riot's aftermath, Gordon suggestively blamed recent currency tumults on "outsiders" of "necessitous Circumstances," a common method of delegitimizing popular disturbance. Yet Gordon's attribution of "heats \& animosities" to irrational strangers of low status could not mask the very real tensions evident in town and country. ${ }^{92}$

In New York, where currency was comparatively abundant, economic arguments in the 1720s focused on taxation rather than paper money. Nevertheless, the connection between debt, money, and unfreedom remained prominent in the colony's economic culture. ${ }^{93}$ In 1726 , an anonymous New

91. "Philadelphus," A View of the Calumnies Lately Spread (Philadelphia, 1729).

92. Hazard et al., Pennsylvania Archives, 8th series, 3:1929-40; Provincial Council Minutes, 3:351-52; Watson, Annals of Philadelphia, 1:79. The late 1720s was indeed a period of large-scale immigration from Ireland and Germany to Philadelphia and Pennsylvania, and it is likely that at least some of those agitating for paper money were non-English immigrants. According to Gordon, the strangers of which he spoke were from neighboring colonies as well as beyond the sea. On immigration to Pennsylvania at this time, see Marianne S. Wokeck, Trade in Strangers: The Beginnings of Mass Migration to North America (University Park: Pennsylvania State University Press, 1999), 41-42. The assembly ultimately raised the emission to thirty thousand pounds. Pennsylvania Statutes, 4:98-116.

93. Prior to the 1730s, economic disputes in New York resembled those of the metropole, specifically whether mercantile or landed rural interests should bear the brunt of the tax system. Bonomi, A Factious People, chap. 3. 
York author appropriated the voice of the honest plowman in a pro-farmer treatise on taxation. Following an urban merchant's lecture to country farmers on the intricacies of trade, a farmer retorted that city traders "encrease our Necessities by encreasing our Poverty: You fancy thereby to make us your Slaves and Drudges, and to get all our Lands Mortgaged to you." Like Roger Plowman of Pennsylvania, the New York farmer claimed that in the long run merchants would themselves suffer from such practices. Yet whereas Plowman's argument that merchants would eventually sink along with farmers and artisans was rooted in an evolving labor theory of value (to wit, if producers sank, so too would those who depended on their labor), the New York husbandman claimed that land dispossession and forced labor turned local producers into shiftless dependents not unlike chattel slaves. As long as farmers and laborers possessed their own property and worked for themselves, they labored industriously; if forced to work for others, they would be no better than slaves and would "grow lazy and careless, neglect both your Interest and our own.” New York pamphleteers applied a racialized binary between freedom and unfreedom to debtorcreditor relations that, potentially, reduced debtors to dependent wage workers, or "mere Negroes." 94

When an economic crisis gripped New York in the late 1720s, the urban press provided a space for a variety of criticisms of colonial policy to emerge. Much like Francis Rawle had blamed the elimination of bolting regulations for Pennsylvania's economic decline in 1721, a number of New York merchants attributed similar problems a decade later to the end of the city's bolting and export monopoly. ${ }^{95}$ As the maritime and West Indian trades declined and debt levels rose, city artisans petitioned urban and provincial authorities for protectionist measures. Some claimed that the repeal of a local tonnage duty drained money from the city and colony, leading to widespread unemployment and emigration. ${ }^{96}$ John Peter Zenger's new

94. [Cadwallader Colden?], The Interest of the Country in Laying Duties; or, a Discourse, shewing how Duties on some Sorts of Merchandize may make the Province of NewYork richer than it would be without them (New York, 1726), 15-16. For the opposing view, see The Interest of the City and Country to lay no Duties; or, a short Discourse shewing that Duties on Trade, tend to the Impoverishing City and Country (New York, 1726); and for a third way, see The Two Interests Reconciled, Occasioned by Two Late Pamphlets, called the Interest of the County and the Interest of the City and Country (New York, 1726).

95. Middleton, Privileges to Rights, 192-93.

96. New-York Weekly Journal, March 18, 1734; Middleton, Privileges to Rights, 194-95. 
New-York Weekly Journal gave voice to letters from figures like "Timothy Wheelwright," who claimed to speak on behalf of impoverished laboring men and women against "Gripe the Lawyer" and "Squeeze the Shopkeeper"-characters indicative of the importance of credit and debt law to the perceived causes of inhabitants' difficulties. ${ }^{97}$ A letter from a city "Trades-man" suggested that the ubiquity of exchange on "trust" in New York was a consequence of the many "griping Userers" in the province, who preferred to lend money out at interest rather than "pay the poor TradesMan for his Labour." Without money for wages, common laborers were forced to borrow at excessive interest to preserve their credit, or to avoid jail. The implication, as in Pennsylvania, was that creditors-assumed by the "Trades-man" to be the same as employers-placed common people in bondage by appropriating the colony's "running Cash" in order to ensnare borrowers when they were unable to repay loans. ${ }^{98}$

By the 1740s, decades of experience with public bills of credit led some colonial writers to reject a long-standing belief in the intrinsic value of gold and silver, and even argue for the superiority of paper money. ${ }^{99}$ In Philadelphia, the lawyer, editor, and political radical John Webbe went further than most in claiming that bills of credit were not instruments of credit, but were in fact actual money if supported by the public. According to Webbe, after the first issuing of paper money in Pennsylvania in 1723, debtors willingly sold goods in exchange for paper. The establishment of paper's credit and the maintenance of its value led lenders (though some wrongly believed that depreciation occurred) to bargain for paper as they had earlier for silver. Webbe also claimed that "intrinsic worth" came not from money, but from the labor and skill that went into commodities' production; the value of land, like that of moveable goods, rose through the industry of the people as well as through population increase. While merchants and "usurers or money-jobbers, land-jobbers and super-numerary officers, with their tribe of retainers and dependents," grew rich from currency scarcity, it was in the interest of society as a whole to have an abundant supply of money. ${ }^{100}$

97. New-York Weekly Journal, September 12, 1734.

98. New-York Weekly Journal, July 8, 1734.

99. In Massachusetts, Hugh Vans argued paper bills were superior to specie; they were also a better measure of value than labor. [Hugh Vans], An Inquiry into the Nature and Uses of Money; More especially of the Bills of Publick Credit, Old Tenor (Boston, 1740), 2-3, 26-27. See also Moore, "Blood that Nourishes the Body Politic."

100. John Webbe, A Discourse Concerning Paper Money, in which Its Principles are Laid Open (Philadelphia, 1743), 4, 7. Webbe was well-known in Philadelphia, having 
The traditional concerns of hard money supporters, specifically over devaluation and its negative effects on creditors, were not absent in the mid-Atlantic. When imaginary paper monies depreciated, as happened in Rhode Island in the 1740s, critics observed debtors in other colonies attempting to repay loans in Rhode Island paper bills of little value. Roger Sherman, a Connecticut lawyer and future Revolutionary leader, complained in a treatise published in New York that bills of credit in general were of no intrinsic value, and that the fluctuating value of paper money often led to substantial creditor losses. According to Sherman (writing as "Philoeunomos"), debtors deceptively evoked a language of customary practice to justify the continuance of payments in Rhode Island money at previous values. Arguments from custom were now of no consequence, however, since in the colonial context of valueless paper money, the reasons for that custom had ceased to exist. At least clipped coins had some intrinsic value; according to Sherman, forcing creditors to accept worthless paper notes because of an erroneous custom was in fact a tyrannical injustice. ${ }^{101}$

If the creation of paper monies in the mid-Atlantic stimulated commerce and made loan repayment possible, it did not eradicate the need for credit or competing ideas regarding money. Indeed, bills of credit and the politicization of money in the press-especially the emergence of voices representing ordinary colonists' interests and language-encouraged more volatile arguments over currency and its function. While some complained of the dangers of imaginary paper money, pro-paper pamphleteers railed against the loan bank trustees and wealthy city traders who continued to manipulate currency for their own interest. The opposite of paper money's embodiment of freedom remained the bondage that resulted from its absence.

\section{DEVALUATION AND POPULAR PROTEST}

Roger Sherman's claim in 1752 that debtors deployed a language of customary exchange rates to repay loans in devalued Rhode Island bills suggests how people in the mid-Atlantic adapted the concept of custom to the region's culture of money. Historians of early modern England have long known that custom provided a legitimizing keyword of political protest, and that some customs were in fact of recent invention. ${ }^{102}$ In the colonial

in 1736 authored a series of radical-democratic letters published under the name of “Z.” Pennsylvania Gazette (Philadelphia), April 8, 22, 1736, and July 22, 1736.

101. [Roger Sherman], A Caveat against Injustice (New York, 1752), 5, 7, 8. See also Priest, "Currency Policies and Legal Development,"1314-15.

102. E. P. Thompson, Customs in Common: Studies in Traditional Popular Culture (New York: New Press, 1993); Andy Wood, The Memory of the People: Custom and Popular Senses of the Past in Early Modern England (New York: Cambridge, 2013). 
mid-Atlantic, debtors and renters opposed the innovative practices of creditors and landlords through petitions in a language of customary rights and obligations, while also embracing new paper money to remedy chronic economic problems. When merchants in Philadelphia and New York City attempted to devalue the copper halfpence at midcentury, critics used a discourse of custom to oppose a novel and extralegal economic scheme. And when traders put devaluation into action, townspeople engaged in another customary form of protest - that of the public demonstration. ${ }^{103}$

In England, the people of Kendal, Halifax, Rochdale, and elsewhere engaged in riots and demonstrations following the implementation of the 1696 Act for remedying the Ill State of the Coin, which nearly halved the value of silver coin in England. ${ }^{104}$ One of England's monetary reforms of the 1690s included a ban on the exportation of silver abroad, including to the Americas. Subsequently, the British copper halfpence, which typically passed at twelve pence to the shilling, became crucial to everyday exchange in the colonies. As they had with other coins, colonists eventually varied the rate of the halfpence, leading to its concentration in places where its value was high. In 1740, which saw an unusually cold winter during which the Delaware River was frozen and necessities were in short supply, leading Philadelphia traders decided to devalue the copper pennies that had driven gold and silver from Pennsylvania. Rather than twelve pence to the shilling, the city's "considerable Dealers" agreed that the pennies would henceforth only be accepted at the much-reduced rate of eighteen per shilling. Shopkeepers followed merchants' example, while bakers refused to bake bread until the confusion over the coin was settled. On a frigid Friday in January, a crowd gathered and proceeded to march across town, breaking the windows of all who refused to accept the coin at the customary rate.

103. Literature on early American crowd action has not examined prerevolutionary crowd action involving currency. Dirk Hoerder, Crowd Action in Revolutionary Massachusetts, 1765-1780 (Cambridge, Mass.: Academic Press, 1977); Alfred F. Young, ed., The American Revolution: Explorations in the History of American Radicalism (DeKalb, Ill.: Northern Illinois University Press, 1976); Alfred F. Young, Liberty Tree: Ordinary People in the American Revolution (New York: New York University Press, 2006); William Pencak, Matthew Dennis, and Simon P. Newman, eds., Riot and Revelry in Early America (University Park: Pennsylvania State University Press, 2002).

104. Historians have estimated that the calling in and recoining of the country's silver resulted in a profit of $£ 2.7$ million for the wealthy, while those unable to send coin to the mint or find buyers may have lost $£ 1$ million. Muldrew, "Hard food for Midas," 107; Joyce Oldham Appleby, "Locke, Liberalism and the Natural Law of Money," Past E' Present 71, no. 1 (May 1976): 43-69; Wennerlind, Casualties of Credit, 152-53. 
Large numbers of townspeople gathered for further demonstrations the following day, "but by the Vigilance and Resolution of some of the Magistrates, they were timely surpress'd, and the City has since remained quiet." 105

Though magistrates were able to prevent further crowd actions, hostility to the devaluation persisted into the spring. While both Philadelphia newspapers were silent on the demonstrations and lingering monetary uncertainty, a broadside appeared that provides a rare popular perspective on the reduction. According to "Dick Farmer," it was city merchants themselves who imported the copper halfpence to pay them out to farmers, millers, and mechanics at an advanced rate. After distributing the change to local producers in wages or as credit, merchants then refused to accept the halfpence as payment for goods or debts at the same rate. Since there was no law to regulate the coin, great confusion had arisen among "all Sorts," but the practice was particularly hard on common laborers, whose wages and ability to purchase necessities were greatly diminished. Only a provincial law restoring the coin's former value could "rescue the People out of the Merchants Power." Appropriating the vox populi, "Farmer" claimed that his proposals were supported by nineteen of twenty persons in the province, and signed the broadside "in behalf of Thousands." 106

The assembly failed to enact Farmer's recommendation, however, and tensions over the halfpence continued into the summer. A meeting of the Philadelphia common council in June acknowledged the protracted "Disquiet" among townspeople regarding the coin and decided to implement a compromise. Instead of eighteen pence to the shilling, the council board proclaimed that the halfpence would thereafter be accepted at fifteen to the shilling, which would ideally avoid the excessive importation of the coin while also preventing the pennies from being entirely driven from the province. Those who persisted in their refusal to accept the halfpence at the stated rate would be deemed disturbers of the peace and punished accordingly. ${ }^{107}$

A strikingly similar disturbance occurred in New York twelve years later. In 1753, New York's Independent Reflector warned against an excessive supply of paper money, arguing that too many bills of credit would deprive the colony of silver. Paper money also introduced excessive wants and a

105. Philadelphia Common Council Minutes, 398-99; Pennsylvania Gazette (Philadelphia), January 8, 1741; New-York Weekly Journal, January 26, 1741.

106. "Dick Farmer," Whereas Great Quantities of English Copper [...] (Philadelphia, 1741).

107. Philadelphia Common Council Minutes, 402; American Weekly Mercury (Philadelphia), July 2, 1741. 
dangerous "Spirit of Extravagance" among the people, since with "imaginary Money" inhabitants purchased imported European goods from local markets. ${ }^{108}$ Equally lamentable was the price of the British halfpence in New York, which overvalued the coin relative to other colonies. Though the author acknowledged that the pennies served a needed function as small change, New York's reckoning of twelve to the shilling was considerably higher than elsewhere; they should therefore be valued at fourteen to the shilling - the "real Value" of the coin. ${ }^{109}$

Rumors surrounding the halfpence devaluation caused general alarm some months later. Late in 1753, an agreement signed by seventy-two New Yorkers stating that the English copper halfpence had lessened the value of New York money appeared in the New-York Weekly Mercury. Signers, including the city's "principal Merchants," would thereafter only accept the halfpence at the rate of fourteen to the shilling-a reduction similar in form though less dramatic than that attempted by Philadelphia merchants the previous decade. ${ }^{110}$ Around the same time, the Mercury refuted rumors that Philadelphians planned to reintroduce the customary halfpence rate because all the coins had been carried away from that city. There was no need to fear that the small change would be wholly driven out of New York. ${ }^{111}$ In early January, city authorities ordered retailers to only accept the pennies at fourteen to the shilling. Though the press emphasized the need for the reform and claimed that New Yorkers were "truly sensible" of the "salutary Effects" that would result from devaluation, Governor James Delancey read a preemptive proclamation against rioting. ${ }^{112}$

Like Dick Farmer in Philadelphia, a lone voice in the New York press spoke in print against the reform in the name of a people opposed to devaluation. A Mercury letter from "A Citizen" claimed that most people continued to pass halfpence at twelve to the shilling despite the publication of the merchants' pact. In fact, the people of New York would never consent to any monetary alteration without a law passed by their elected representatives.

108. This statement fused classical republican suspicions of luxury and fears of trade imbalances with utility of poverty theories, which claimed that working people would only labor industriously if forced to through hunger and poverty.

109. Independent Reflector (New York), May 24, 1753.

110. New York signers claimed that the real value of the copper halfpence was in fact considerably less than fourteen due to the poor quality of the copper, but they followed the Reflector writer in allowing for the change's importance to local exchange. New-York Weekly Mercury, December 24, 1753.

111. New-York Weekly Mercury, January 7, 1754.

112. New-York Weekly Mercury, January 14, 1754. 
Money was a matter of the public interest, and since any "Idiot might know" that the vast majority of New Yorkers opposed devaluation, signers had met in secret to implement an illegal policy. "For a sett of Men to meet at a Coffee-House, and there propose Laws to rule the Province, is absurd, inconsistent and ridiculous." In addition to violating basic principles of justice and representative government, reducing the shilling would cause serious hardship for poor consumers while also reducing laborers' wages. A Citizen claimed, again like Philadelphia's Farmer, that "Every Body knows" it was merchants who imported the pennies and then paid them out as wages. "Is it not strange, that Men who have been the Instruments of importing them, should fall on such Methods to oppress the Public? Every honest Man, I dare say, will think it monstrous, illegal, cruel and inhumane."113

Similarities with Philadelphia did not end there, for when the devaluation went into effect, townspeople protested across the city. Considerable planning went into the crowd action: according to the sole report of the event (provided in a Philadelphia, not New York, newspaper), "great Numbers" gathered early in the morning of January 11 at various points in the city - possibly in the vicinity of the town's five markets. ${ }^{114}$ After assembling at an unspecified meeting point, more demonstrators appeared in the city's streets, armed, as was customary, with clubs and staves while a drum beat at the head of the procession. Prepared for trouble, Governor Delancey issued an emergency proclamation from Fort George ordering rioters to disperse on pain of rigorous prosecution. He also mobilized all city officials, from the mayor and aldermen down to the sheriff and constables, to aid in the suppression of the demonstrations. Authorities eventually overpowered protesters, with Delancey himself reportedly taking an active role in apprehending and punishing the riot's leaders. ${ }^{115}$

An official grand jury report on the riots represented protesters as deluded outsiders of low circumstances in language reminiscent of Governor Gordon's portrayal of Philadelphia demonstrations in 1729. According to the grand jury, rioters were "Strangers" to New York, "weak People" ignorant of government and "Inhabitants of the World, assembled here by meer

113. New-York Weekly Mercury, January 7, 1754.

114. In contrast to Philadelphia's large market in the center of town, in New York there were five smaller public markets distributed throughout the city. Arthur Everett Peterson and George William Edwards, New York as an Eighteenth Century Municipality (Port Washington, N.Y.: Ira J. Friedman, Inc., 1967), 60-61, 70-71.

115. Pennsylvania Gazette (Philadelphia), January 22, 1754; William Smith Jr., The History of the Province of New-York, 2 vols., ed. Michael Kammen (Cambridge: Harvard University Press, 1972), 2:149. 
Chance." Townspeople "of Reputation," by contrast, were wholly uninvolved in the tumult. Aside from their alleged poverty and alien status, all that the grand jury stated about the protesters was that they justified their action as "the Cause of the Poor." ${ }^{116}$ The official representation of the crowd actions as undertaken by outsiders ignorant of government and lacking status was an obvious attempt to discredit those involved while publicizing the lack of participation of the city's "better sort." It is therefore notable that if the mid-Atlantic urban press was instrumental in allowing a space for the expression of different ideas regarding money and credit between the 1720 s and 1750 s, printers were either silent on or condemnatory of crowd actions involving currency policy.

\section{CONCLUSION}

In his History of the Province of New-York, first published in 1757, William Smith Jr. called the 1754 halfpence demonstration in New York City "inconsiderable," an "ineffectual tumult" led by a mob. ${ }^{117}$ Though historians have generally followed Smith's dismissive assessment, early Americanists should be aware that colonial elites' desire to set the terms of currency debate-regardless of their individual position on paper money-led them to downplay or ignore the extent of popular engagement with money as a political issue. ${ }^{118}$ The discrediting of public demonstrations over currency policy, whether through law enforcement or the press, are in fact demonstrative of the salience of money as a sociopolitical issue, and of authorities' anxieties regarding currency's potency as a cultural signifier of oppression or liberation. These tensions and anxieties extended to debt relations and to the potential loss of property or bodily freedom that resulted from default.

Benjamin Franklin's famous "The Way to Wealth" essay perhaps best demonstrates how what had been a deeply contested moral and political issue was depoliticized in a language of individual responsibility at midcentury. First appearing in the 1758 edition of Poor Richard's Almanac, "The Way to Wealth" is revealing in what it says—and does not say-about economic and social relations in the eighteenth-century mid-Atlantic.

116. New-York Weekly Mercury, January 21, 1754.

117. Smith, History of the Province of New-York, 2:149.

118. Paul Gilje has claimed that the 1754 coinage riot was a rare instance of patrician-plebeian conflict in early New York. Paul Gilje, The Road to Mobocracy: Popular Disorder in New York City, 1763-1834 (Chapel Hill: University of North Carolina Press, 1987), 14. The demonstration is also mentioned in passing in Edwin G. Burrows and Mike Wallace, Gotham: A History of New York to 1898 (New York: Oxford University Press, 1999), 182. 
According to the character of Father Abraham, who lectures colonists at a merchant vendue (where some of the goods for sale would have belonged to debtors) on the evils of luxury, going into debt was equated with placing oneself in bondage: "Your Creditor has Authority at his Pleasure to deprive you of your Liberty, by confining you in Gaol for Life, or to sell you for a Servant, if you should not be able to pay him!" Although this statement would have resonated among many in the mid-Atlantic, currency is conspicuously absent from the essay. Rather than address lending practices and interest, exchange rates, or money supply, Abraham blamed colonists' extravagant desire to consume beyond their means for the loss of freedom that accompanied debt. Franklin placed sole responsibility on the individual borrower, and substituted personal freedom for the public good: "The Borrower is a Slave to the Lender, and the Debtor to the Creditor, disdain the Chain, preserve your Freedom; and maintain your Independency: Be industrious and free; be frugal and free."119

The few scholars who have addressed the forced labor that resulted from default have echoed Franklin's commonsense individualism. Richard Morris wrote in his classic Government and Labor in Early America that in laborscarce America, placing debtors in jail was simply a "waste of manpower." Hence, from an early period, colonies enacted laws that allowed individual debtors to serve creditors or their assigns for a term to satisfy the debt. ${ }^{120}$ Such a view neglects the politics of money as well as the deep cultural enmity to the loss of liberty-whether through the seizure of property, debtor's prison, or forced labor-occasioned by indebtedness in the early modern world. ${ }^{121}$ Colonial laws that sanctioned new forms of unfreedom in the seventeenth-century mid-Atlantic were met in subsequent decades with

119. Benjamin Franklin, “The Way to Wealth,” in Paul Lauter et al., eds., Heath Anthology of American Literature, 5th ed. (Boston: Houghton Mifflin, 2006), vol. A, 812. Franklin's partial borrowing of Proverbs 22:7 reverses the moral lesson of the biblical verse, which was in fact a caution not to borrowers but to those who would oppress the poor through avarice. The original Waie to Wealth, written in the middle of the sixteenth century by Robert Crowley, was an anti-enclosure tract. In the past, Franklin had been a cautious supporter of paper money and had benefitted personally from the printing of bills of credit.

120. Morris, Government and Labor, 355.

121. Some enslaved persons in the Americas may have been familiar with the concept of debt bondage in Africa. For very different Cherokee ideas regarding debt, see Tom Hatley, The Dividing Paths: Cherokees and South Carolinians through the Era of Revolution (New York: Oxford University Press, 1993), 48. For the general European context, see Laurence Fontaine, The Moral Economy: Poverty, Credit, and Trust in Early Modern Europe (New York: Cambridge University Press, 2014). 
petitions, publications, and direct actions that challenged statutes and merchant practices, thereby maintaining currency and credit relations as objects of debate and controversy.

Daniel Vickers rightly suspected that credit in early America was an instrument of economic power that could become the focus of social tensions. Yet it was in the colonies of New York and Pennsylvania where those tensions were most politically and culturally constitutive, and the most long-lasting. Not only did the practice of debt bondage endure longer there than in other colonies, but it was in the mid-Atlantic where a unique theory of creditor oppression developed as well, and where paper money consequently came to embody freedom in a novel way. ${ }^{122}$ As people throughout the Atlantic world increasingly questioned a belief in the intrinsic value of silver and gold, some articulated new ideas around the nature of money and the source of value. If labor came to constitute one important foundation for the creation of value, being forced to give one's labor to another following default compounded the humiliation of dependence in a region in which racial slavery was prominent. The belief that persons in positions of power used that power to appropriate the lands and labor of producers through the instrumentalization of credit deeply animated economic, cultural, and political life in the colonial mid-Atlantic. Recognition of that fact provides an important new dimension to the perennial subject of colonial unfreedom, while also placing social conflict over debt and monetary policy at the center of new histories of early modern capitalism.

122. In 1767, a frustrated New York writer lamented that "the Cries of all Ranks of People" were for paper money since local jails were full of people incarcerated for "very trifling Debts." "A Linen Draper," The Commercial Conduct of the Province of New-York Considered (New York, 1767), 5, 13. Around the same time, the social reformer John Woolman wrote that as a young man he was by nature inclined to "sympathize with those whose circumstance in life as free men required constant labour to answer the demands of their creditors, and with others under oppression." John Woolman, The Journal and Major Essays of John Woolman, ed. Phillips P. Moulton (Richmond, In.: Friends United Press, 1971), 118-19. See also John Woolman, Considerations on Pure Wisdom, and Human Policy; On Labour; On Schools; And on the Right Use of the Lord's Outward Gifts (Philadelphia, 1768), 12, 14, 21. 